\title{
Description of Rhabdochona (Globochona) rasborae sp. n. (Nematoda: Rhabdochonidae) from the freshwater cyprinid fish Rasbora paviana Tirant in southern Thailand
}

\author{
František Moravec $^{1}$ and Kanda Kamchoo ${ }^{2}$
}

\author{
${ }^{1}$ Institute of Parasitology, Biology Centre of the Academy of Sciences of the Czech Republic, Branišovská 31, 37005 České \\ Budějovice, Czech Republic; \\ ${ }^{2}$ Faculty of Sciences and Industrial Technology, Prince of Songkla University, Surat Thani Campus, Surat Thani 84 000, Thailand
}

\begin{abstract}
A new nematode species, Rhabdochona (Globochona) rasborae sp. n. (Rhabdochonidae), is described from the intestine of the freshwater cyprinid fish (sidestripe rasbora) Rasbora paviana Tirant in the Bangbaimai Subdistrict, Muang District, Surat Thani Province, southern Thailand. It differs from other representatives of the subgenus Globochona Moravec, 1972 which possess eggs provided with lateral swellings in having a spinose formation at the tail tip of both sexes and in some other morphological features, such as the body length of gravid female $(8.6-23.7 \mathrm{~mm})$, presence of two-three swellings on the egg, eight anterior prostomal teeth, length ratio of spicules $(1: 5.3-6.7)$ and arrangement of male genital papillae. This is the third nominal species of Rhabdochona Railliet, 1916 and the second species of the subgenus Globochona reported from fishes in Thailand. The three species of Rhabdochona recently described from fishes in Pakistan, viz. R. annai Kakar, Bilqees et Khan, 2012, R. bifurcatum [sic] Kakar et Bilqees, 2012, and $R$. pakistanica Kakar, Bilqees et Khan, 2012, are considered to be species inquirendae.
\end{abstract}

Keywords: parasitic nematode, Rhabdochona, Globochona, freshwater fish, sidestripe rasbora, Cyprinidae, Thailand

As recently stated by Moravec and Yooyen (2011a), the fauna of freshwater fish nematodes in Thailand remains little known. The records of these parasites in Thailand inlad waters have been rather scarce (Pearse 1933, Ratanasritong and Kliks 1972, Sirikanchana 1982, Moravec and Scholz 1991, Moravec et al. 1999, 2004, 2006, 2007, 2011, Wongsawad et al. 2004, Boonchot and Wongsawad 2005, Purivirojkul 2009, Moravec and Yooyen 2011a,b) and the reported parasites often were not identified to species. Kumchoo (2000) [presently transcribed from Thai as Kamchoo] was the first to record representatives of the genus Rhabdochona Railliet, 1916 in her unpublished thesis, reporting four unidentified species, designated as Rhabdochona sp. and Rhabdochona spp. I-III, from nine species of fishes in the Maesa Stream, Doi SuthepPui National Park, Chiang Mai, northern Thailand. Later the same unidentified Rhabdochona spp. from fishes of this locality were reported in the paper of Wongsawad et al. (2004). Two new species of Rhabdochona, R. (Rhabdochona) pseudomysti Moravec et Yooyen, 2011 and R. (Globochona) thaiensis Moravec et Yooyen, 2011, have recently been described from Pseudomystus siamensis (Regan) and Mystacoleucus marginatus (Valenciennes), respectively, from northern Thailand (Moravec and Yooyen 2011a).
During recent helminthological investigations on some freshwater fishes in the Surat Thani Province, southern Thailand, nematodes referable to Rhabdochona were recovered from the intestine of the sidestripe rasbora Rasbora paviana Tirant (Cyprinidae, Cypriniformes). Their detailed study using the light and scanning electron microscopy showed that they represent a previously undescribed species belonging to the subgenus Globochona Moravec, 1972. This species is described herein.

Rasbora paviana (maximum body length $12 \mathrm{~cm}$ ) is a tropical freshwater fish of minor commercial importance, which is native in Thailand. Its distribution includes the Mekong, Chao Phraya and Meklong basins, being also reported from the northern Malay Peninsula (Froese and Pauly 2012).

\section{MATERIALS AND METHODS}

Fish were collected by a local fisherman using gill nets from a small tributary creek of the Tapi River in the Bang Baimai Subdistrict, Muang District, Surat Thani Province. Thirty-five specimens of Rasbora paviana (total body length 9.0-12.8 [mean 10.3] cm, weight 4-18 [9.3] g) were examined for parasites during March and April of 2011. The nematodes recovered were washed in physiological saline and then fixed in cold $4 \%$ formaldehyde solution. For light microscopy (LM) examina-

Address for correspondence: F. Moravec, Institute of Parasitology, Biology Centre of the Academy of Sciences of the Czech Republic, Branišovská 31, 37005 České Budějovice, Czech Republic. Phone: +420 38777 5432; Fax: +420 38531 0388; E-mail: moravec@paru.cas.cz 
tion, the nematodes were cleared with glycerine. Drawings were made with the aid of a Zeiss drawing attachment. Specimens used for scanning electron microscopy (SEM) were postfixed in $1 \%$ osmium tetroxide (in phosphate buffer), dehydrated through a graded acetone series, critical-point-dried and sputter-coated with gold; they were examined using a JEOL JSM-7401F scanning electron microscope at an accelerating voltage of $4 \mathrm{kV}$ (GB low mode). All measurements are in micrometres unless otherwise indicated. The names of fishes follow FishBase (Froese and Pauly 2012).

\section{RESULTS}

\section{Family Rhabdochonidae Travassos, Artigas et} Pereira, 1928

\section{Rhabdochona (Globochona) rasborae sp. n.}

Figs. 1, 2

Description: Medium-sized nematodes with finely transversely striated cuticle. Oral aperture hexagonal to oval, with four submedian sublabia, surrounded by four small submedian cephalic papillae and pair of lateral amphids (Figs. 1E, 2A,B). Prostom barrel-shaped, with distinct basal teeth (Fig. 1C,D). Anterior margin of prostom armed internally with eight fairly large, forwardly directed teeth (two dorsal, two ventral and two on each side) (Figs. 1E, 2A,B). Vestibule long (Fig. 1A-C). Deirids small, bifurcate, situated at posterior half of vestibule (Figs. 1B,C,F, 2H). Glandular oesophagus 8-15-times longer than muscular oesophagus, occupying entire width of body (Fig. 1A). Tail of both sexes conical with truncated tip, optically forming two minute (dorsal and ventral) posteriorly oriented spikes (Fig. $1 \mathrm{~N}, \mathrm{O}$ ); in fact, this is ring of elevated cuticle with sharp edge, bearing about three thickenings; small terminal mucron provided with many minute spine-like projections arises from middle of above-mentioned cuticular ring (Fig. 2F,G).

Male (seven specimens; measurements of holotype in parentheses): Length of body 5.55-6.12 (5.63) mm, maximum width 68-82 (68). Prostom 12 (12) long and 12 (12) wide in lateral view. Length of vestibule including prostom 114-120 (117). Muscular oesophagus 135-240 (168) long, maximum width 15-21 (15); glandular oesophagus 1.56-2.01 (1.77) mm long, maximum width 42-60 (48); length ratio of both parts $1: 8-13(1: 11)$. Length of vestibule with prostom and entire oesophagus forms 33-40 (35)\% of body length. Nerve ring encircling muscular oesophagus 156-174 (171) from anterior extremity; excretory pore at 210-246 (228). Deirids not located. Preanal papillae: 7-8 (7) subventral and 1 (1) lateral pairs; latter situated at about level of, or somewhat posterior to, third pair of subventrals (counting from cloacal opening) (Figs. 1S, 2D). Postanal papillae: 6 (6) pairs, of which 5 (5) pairs subventral and 1 (1) lateral; lateral pair approximately at level of first pair of subventrals or slightly posterior to it (Figs. 1S, 2C,D). Precloacal ventral cuticular ornamenta- tion (area rugosa) formed by numerous transverse bands separated from each other by single transverse groove, each provided with band-like field bearing many low longitudinal, parallel ridges (Figs. 1K, 2E). Left spicule 399-456 (441) long; its shaft 75-108 (90) long, representing 16-26 (20)\% of entire spicule length; distal tip of extruded spicule slightly widened, blunt (Figs. 1R,S, 2C,D). Right spicule boat-shaped, 66-81 (66) long, without dorsal barb at distal tip (Fig. 1P,S). Length ratio of spicules $1: 5.3-6.7$ (1:6.7). Tail 141-204 (204) long (Figs. $1 \mathrm{~S}, 2 \mathrm{C}, \mathrm{D})$; terminal mucron bearing cuticular spines 6 (6) long and 4.5-6 (6) wide (Figs. 1N,S, 2C,D,F,G).

Female (five gravid specimens with mature eggs; measurements of allotype in parentheses. Measurements of five nongravid and those containing few immature eggs in square brackets): Length of body 8.64-23.72 (12.68) [4.27-6.64] mm, maximum width 109-272 (150) [68-95]. Prostom 15-21 (21) [9-18] long and 12-18 (18) [9-15] wide in lateral view. Length of vestibule including prostom 114-156 (132) [102-126]. Muscular oesophagus 165-198 (198) [153-165] long, maximum width 21-30 (30) [15-21]; glandular oesophagus 2.12-2.86 (2.86) [1.51-2.07] mm, maximum width 60-75 (75) [42-57]; length ratio of both parts $1: 12-15(1: 14)[1: 10-13]$. Length of vestibule with prostom and entire oesophagus forms $12-28$ (25) [29-41]\% of body length. Nerve ring, excretory pore and deirids at 168-213 (213) [150-168], 204-294 (276) [210-243] and 57-117 (not located) [6987], respectively, from anterior extremity. Vulva postequatorial, 4.76-13.15 (7.48) [2.54-3.92] mm from anterior extremity, at 53-65 (59) [58-64]\% of body length. Vagina directed first anteriorly and then posteriorly from vulva (Fig. 1L). Mature eggs oval, thick-walled, larvated, provided with two large oval, almost opposite lateral swellings (floats) (Fig. 1G,H); some eggs bearing one additional, smaller and almost circular equatorial swelling situated between two large swellings (Fig. 1I,J); swellings absent or poorly developed on immature eggs. Size of mature eggs 39-42 × 18-21 (39-42 × 18-21), egg-wall 3 (3) thick, swellings 6-9 (6-9) high. Tail 237-340 (246) [153-286] long (Fig. 1M); caudal mucron bearing spines 6 (6) [5-6] long and 5-6 (6) [6] wide.

Type host: Sidestripe rasbora, Rasbora paviana Tirant, 1885 (Cyprinidae, Cypriniformes).

Site of infection: Intestine.

Type locality: Small tributary creek of the Tapi River, Bang Baimai Subdistrict, Muang District, Surat Thani Province, southern Thailand (collected in March and April 2011).

Prevalence and intensity of infection: 40\% (14 fish infected/35 fish examined); 1-7 (mean 3) nematodes per fish.

Deposition of type specimens: Helminthological Collection of the Institute of Parasitology, BC AS CR in České Budějovice, Czech Republic (Cat. No. N-994).

Etymology: The specific name rasborae (genitive) relates to the generic name of the host fish (Rasbora). 

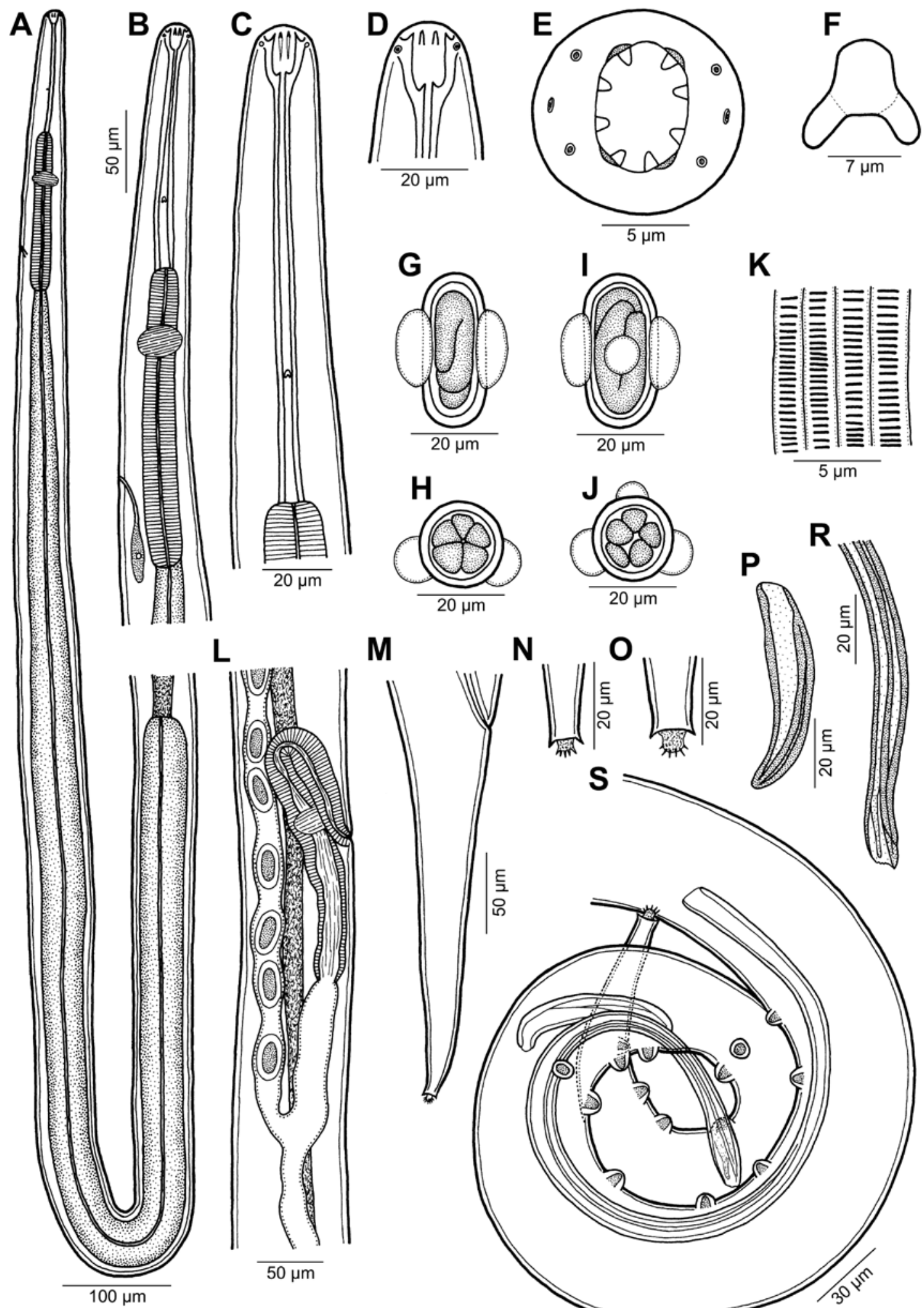

K
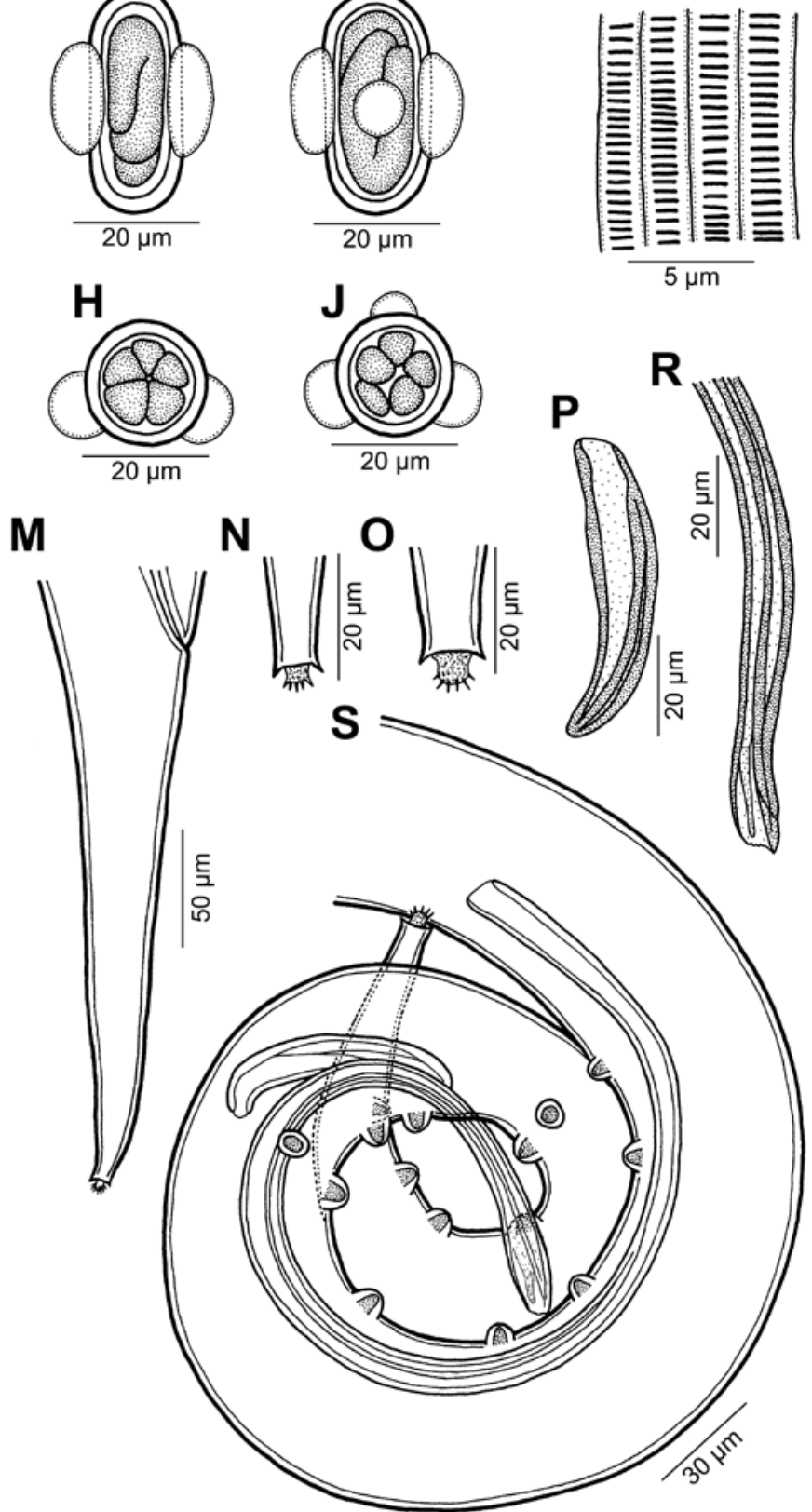

Fig. 1. Rhabdochona (Globochona) rasborae sp. n. A - oesophageal part of male, lateral view; B - anterior end of female, lateral view; $\mathbf{C}$ - region of vestibule of largest female, lateral view; $\mathbf{D}, \mathbf{E}$ - cephalic end, lateral and apical views; $\mathbf{F}$ - deirid; $\mathbf{G}, \mathbf{H}$ - egg with two swellings, lateral and apical views; $\mathbf{I}, \mathbf{J}$ - egg with three swellings, lateral and apical views; $\mathbf{K}$ - detail of male ventral precloacal ornamentation; $\mathbf{L}$ - region of vulva of female containing immature eggs, lateral view; $\mathbf{M}$ - tail of female, lateral view; $\mathbf{N}, \mathbf{O}$ - tail tip of male and female, respectively; $\mathbf{P}$ - right spicule, lateral view; $\mathbf{R}$ - distal end of left spicule, lateral view; $\mathbf{S}$ - posterior end of male, lateral view. 


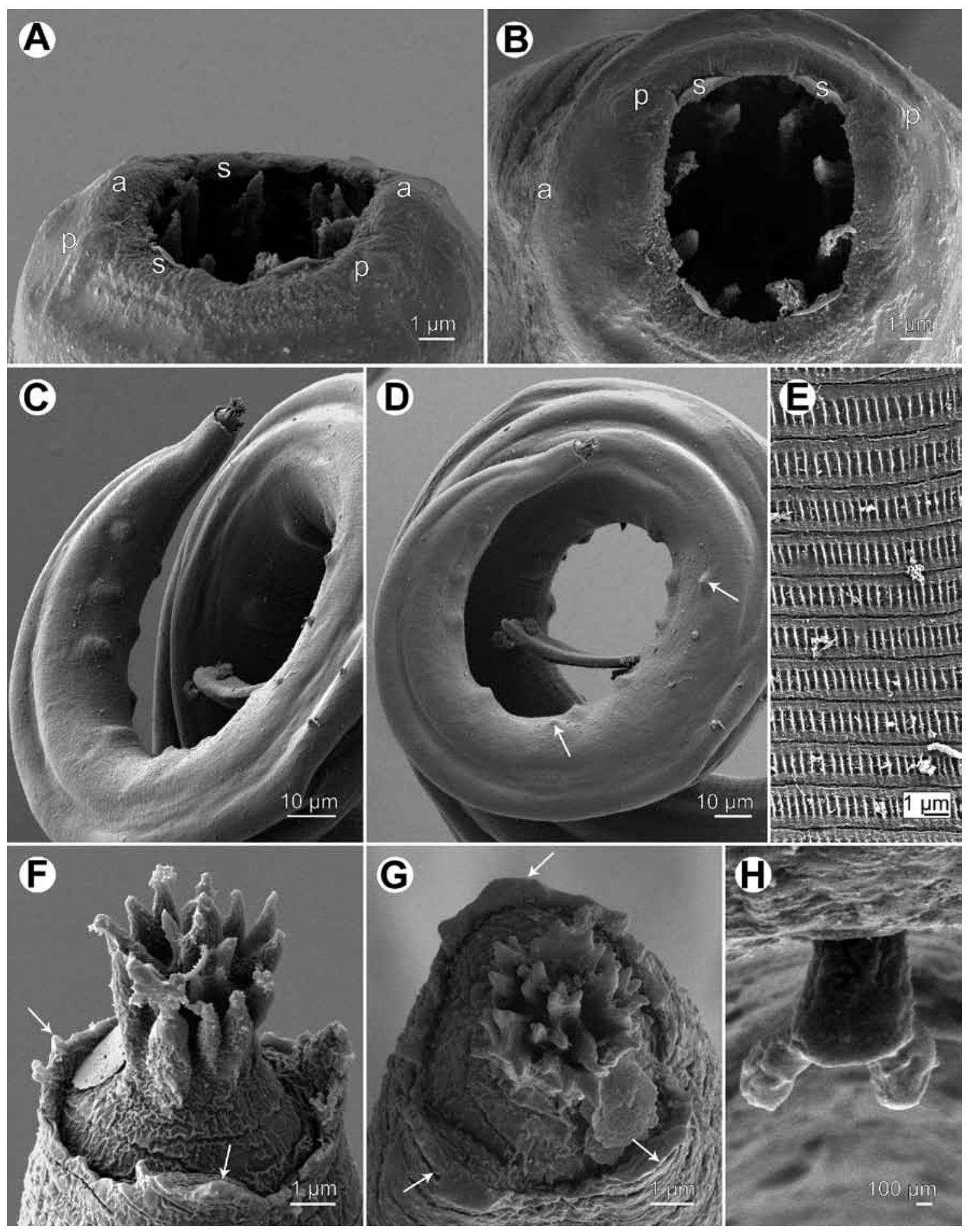

Fig. 2. Rhabdochona (Globochona) rasborae sp. n., scanning electron micrographs. A, B - cephalic end, lateral and apical views; $\mathbf{C}$ - tail of male, subventral view; D - posterior end of male, lateral view (arrows indicate lateral preanal and postanal papillae); $\mathbf{E}$ - ventral precloacal cuticular ornamentation of male; $\mathbf{F}, \mathbf{G}$ - tail tip of male, ventral and apical views (arrows indicate thickenings of cuticular ring surrounding central spiny outgrowth); H - deirid. Abbreviations: a - amphid; p - cephalic papilla; s - sublabium.

Remarks. The genus Rhabdochona includes a large number of species parasitizing the intestine of freshwater fishes in all zoogeographical regions (Moravec 2010). At present, 96 species of this genus can be considered to be possibly valid (Moravec et al. 2012a,b). An additional three species, viz. R. annai Kakar, Bilqees et Khan, 2012, R. bifurcatum [sic] Kakar et Bilqees, 2012 and R. pakistanica Kakar, Bilqees et Khan, 2012, have recently been described from fishes in Pakistan (Kakar and Bilqees 2012, Kakar et al. 2012a,b). However, considering their poor 
and evidently confused descriptions not corresponding to the requirements of the present nematode taxonomy, all of them should be taken for species inquirendae.

Based on the number (8) of anterior prostomal teeth, absence of lateral alae and the presence of caudal projections on the tip of the tail, nematodes of the present material can be assigned to the subgenus Globochona, as re-diagnosed by Moravec (1975). Only a few species of Rhabdochona (Globochona) are known from freshwater fishes in tropical and subtropical Asia and Africa (Moravec 1975, 2010, Boomker and Petter 1993, Wang et al. 1994, Moravec et al. 2010, 2012a, Moravec and Yooyen 2011a). Rhabdochona (Globochona) bagarii Wang et Guo, 1983 proved to be a homonym to Rhabdochona bagarii Gupta et Srivastava, 1982 [species inquirenda] and, therefore, it was renamed $R$. wangi by Moravec and Scholz (1991).

Of the Rhabdochona (Globochona) species, only the following six are characterized by the eggs provided with conspicuous lateral swellings (floats): $R$. (G.) bariliusi Soota et Sarkar, 1981 from Barilius bendelisis (Hamilton) in India; R. (G.) barusi Majumdar et De, 1971 from Barilius sp. in India; R. (G.) gambiana Gendre, 1922 from an unidentified fish, Barbus eutaenia Boulenger and Raiamas moori (Boulenger) in Africa (Gambia and the Democratic Republic of Congo); R. (G.) singhi Ali, 1956 from Glossogobius giuris (Hamilton) in India; R. (G.) rahimi Ghazi, Nisa et Bilqees, 2003 from Barilius pakistanicus Mirza et Sadiq in Pakistan; and $R$. (G.) wangi Moravec et Scholz, 1991 from Bagarius bagarius (Hamilton) and Zacco platypus (Temminck et Schlegel) in China (Ali 1956, Majumdar and De 1971, Moravec 1972, Soota and Dey Sarkar 1981, Wang and Guo 1983, Ghazi et al. 2003).

However, in contrast to the all above-mentioned six species, R. rasborae sp. n. is noted for the presence of a characteristic, well-developed spinose formation at the tail tip of both the male and female, whereas a similar spinose caudal formation is present on the tail tip of female but absent in the conspecific male in $R$. barusi and $R$. wangi; the female tail tip of $R$. gambiana is covered by many minute cuticular points, but that of the male is rounded and smooth (Moravec 1972); the tail tips of both sexes are simple, without any outgrowths, in $R$. bariliusi, R. ghazi and R. singhi.

In addition, $R$. bariliusi, $R$. barusi and $R$. gambiana are reported to have their eggs provided with 4 (vs. 2-3) equatorial swellings. The body lengths of gravid females with mature eggs are comparable with that of the new species only in $R$. bariliusi $(11.9-13.5$ vs. $8.6-23.7 \mathrm{~mm})$ and $R$. wangi $(8.3-13.6 \mathrm{~mm})$, whereas the females of the remaining species are distinctly shorter, not exceeding $7.5 \mathrm{~mm}$ (mostly less than $6 \mathrm{~mm}$ ). Moreover, unlike the new species, $R$. barusi has nine (vs. six) pairs of postanal papillae and the distal end of its small spicule is bifurcated, whereas $R$. wangi is reported to possess seven pairs of asymmetrically arranged postanal papillae.

\section{DISCUSSION}

Data provided by Kumchoo (2000), Wongsawad et al. (2004) and Boonchot and Wongsawad (2005) have indicated that Rhabdochona spp. are common parasites of fishes in Thailand, occurring there in many fish host species belonging to different families. Consequently, it can be assumed that there is a high degree of the species diversity of these nematodes in this zoogeographically very interesting and ecologically varied, but hitherto little explored region. To date, including results of this paper, three nominal species of Rhabdochona, R. (R.) pseudomysti, $R$. (G.) rasborae and $R$. (G.) thaiensis, have been recorded from Thailand (Moravec and Yooyen 2011a, present study), all representing forms endemic to this country. However, it can be expected that many other congeneric species will be discovered and described in Thailand.

It is worth mentioning that the recently described Thai species of Rhabdochona exhibit some unique or rare morphological features within this genus, such as the shape of deirids in $R$. pseudomysti or caudal structures in $R$. rasborae and $R$. thaiensis. A remarkable feature of $R$. (G.) rasborae is the structure of the male ventral precloacal ornamentation (area rugosa). As mentioned by Moravec et al. (2012c), in some Rhabdochona (Rhabdochona) spp. this male ventral cuticular ornamentation is formed, similarly to some cystidicolids, by several longitudinal ridges or is completely missing. In contrast, in $R$. (G.) rasborae the area rugosa is represented by many cuticular transverse bands bearing numerous short longitudinal ridges (Figs. 1K, 2E). To date, a similar structure of the area rugosa has been reported only for the recently described species belonging to the same subgenus, Rhabdochona (G.) kurdistanensis Moravec, Bilal et Abdullah, 2012 from Luciobarbus kersin (Heckel) (Cyprinidae) in northern Iraq (Moravec et al. 2012a) and the African species R. (G.) paski Baylis, 1928 (Puylaert 1973, Moravec, unpublished).

The morphology of $R$. (G.) rasborae is also remarkable for the presence of a "spinose formation" at the tail tip of both sexes. Numerous small cuticular outgrowths at the tail tip of females or of both sexes are characteristic mainly of some Rhabdochona species of the subgenera Globochona and Globochonoides Moravec, 1975, but also of one species ( $R$. salgadoi Caspeta-Mandujano et Moravec, 2000 in Mexico) belonging to the nominotypical subgenus Rhabdochona (see Caspeta-Mandujano and Moravec 2000, Moravec 2010). Because of the small size of these caudal cuticular structures, it is almost impossible to study them in detail by LM. However, recent SEM studies of these caudal formations in a few species of Rhabdochona (see Caspeta-Mandujano and Moravec 2000, Moravec and Yooyen 2011a, Moravec et al. 2012a,c, present study) have shown substantial interspecific differences in their structure. 
Only two ventral claw-shaped projections are present on the tail tip of $R$. (G.) thaiensis, two lateral denticulate outgrowths, each bearing four horn-like projections, are found on that of $R$. (G.) kurdistanensis (see Moravec and Yooyen 2011a, Moravec et al. 2012a), and the female tail tip of $R$. (G.) coronacauda Belous, 1965 bears two broad lateral outgrowths, each with 4-8 digit-like projections surrounding a smooth central area demarcated by both outgrowths (Moravec et al. 2012d). The female tail tip of $R$. (R.) salgadoi is provided with a small terminal rose-shaped outgrowth bearing numerous digit-like projections. In contrast, the male and female tail tips of $R$. (G.) rasborae have a somewhat more complex structure, where the terminal rose-shaped outgrowth bearing numerous digit-like projections is surrounded by a ring of elevated, thickened cuticle appearing in LM as two small spines in lateral view (Figs. 1N,O, 2F,G). As mentioned by Moravec et al. (2012d), the detailed structure of such a caudal formation on the tail tip may serve as an important taxonomic feature in some Rhabdochona spp.
Various aquatic insects (largely ephemeropterans and less often trichopterans and plecopterans) were found to serve as intermediate hosts for some Rhabdochona spp. (see Anderson 2000, Moravec 2010), but the life cycles of the representatives of this genus occurring in Thailand remain unknown. Therefore, observations on the transmission of these parasites in natural conditions as well as experimental studies on the life cycles and larval morphogenesis of Thai species of Rhabdochona are highly needed.

Acknowledgements. We thank the Science Laboratory and Equipment Center, Prince of Songkla University, Surat Thani Campus, Thailand, for providing necessary facilities to the junior author. Authors' thanks are also due to the staff of the Laboratory of Electron Microscopy, Institute of Parasitology, Biology Centre of the AS CR, České Budějovice for their technical assistance, and to Blanka Škoríková of the same Institute for help with illustrations. This study was partly supported by the Czech Science Foundation (grant No. P505/12/G112) and the Institute of Parasitology, BC AS CR (institutional support RVO:60077344).

\section{REFERENCES}

Ali S.M. 1956: Studies on the nematode parasites of fishes and birds found in Hyderabad State. Ind. J. Helminthol. 8: 1-83.

Anderson R.C. 2000: Nematode Parasites of Vertebrates. Their Development and Transmission. 2nd Edition. CABI Publishing, Wallingford, UK, $650 \mathrm{pp}$.

Boonchot K., Wongsawad C. 2005: A survey of helminths in cyprinoid fish from the Mae Ngad Somboonchon Reservoir, Chiang Mai Province, Thailand. Southeast Asian J. Trop. Med. Publ. Hlth. 36: 103-107.

Boomker J., Petter A.J. 1993: Parasites of South African freshwater fish. III. Rhabdochona (Rhabdochona) versterae $\mathrm{n}$. $\mathrm{sp}$. (Nematoda: Rhabdochonidae) from the spot-tailed robber, $\mathrm{Al}$ estes imberi Peters 1852. Onderstepoort J. Vet. Res. 60: 23-27.

Caspeta-Mandujano J.M., Moravec F. 2000: Two new intestinal nematodes of Profundulus labialis (Pisces, Cyprinodontidae) from fresh waters in Mexico. Acta Parasitol. 45: 332-339.

Froese R., Pauly D. (Eds.) 2012: FishBase. World Wide Web electronic publication, www.fishbase.org, version 06/2012.

Ghazi R.R., Nisa N., Bilqees F.M. 2003: First report of the genus [sic] Rhabdochona (Globochona) rahimi sp. n. from a fresh water fish Brilius [sic] pakistanicus in Pakistan. Acta Parasitol. Turc. 27: 217-221.

Kakar A., Bilqees F.M. 2012: A new rhabdochonid species (Nematoda: Rhabdochonidae) parasitizing Cyprinion watsoni (Cyprinidae) in Pakistan. Pakistan J. Zool. 44: 545-550.

Kakar A., Bilqees F.M., Khan A. 2012a: On a new species of spirurid nematode Rhabdochona (Rhabdochona) annai (Spirurida: Thelazioidea) from freshwater mahseer, Tor putitora (Ham.). Pakistan J. Zool. 44: 845-849.

Kakar A., Bilqees F.M., Khan A. 2012b: A new parasitic nematode species Rhabdochona pakistanica, new species from Cyprinion watsoni (Osteichthyes: Cyprinidae) in central Balochistan. Pakistan J. Zool. 44: 851-857.

Kumchoо K. 2000: Survey of Nematodes and SEM of Tegument in Freshwater Fishes From Maesa Stream, Doi Suthep-Pui
National Park, Chiang Mai Province. M.Sc. thesis, Faculty of Science, Chiang Mai University, 168 pp. (In Thai with English abstract).

Majumdar G., De N.C. 1971: Rhabdochona barusi sp. nov. from the fish Barilius sp. with the key to the Indian species of this genus. Folia Parasitol. 18: 381-384.

Moravec F. 1972: A revision of African species of the nematode genus Rhabdochona Railliet, 1916. Acta Soc. Zool. Bohemoslov. 36: 196-208.

Moravec F. 1975: Reconstruction of the Nematode Genus Rhabdochona Railliet, 1916 with a Review of the Species Parasitic in Fishes of Europe and Asia. Studie ČSAV No. 8. Academia, Prague, $104 \mathrm{pp}$.

Moravec F. 2010: Some aspects of the taxonomy, biology, possible evolution and biogeography of nematodes of the spirurine genus Rhabdochona Railliet, 1916 (Rhabdochonidae, Thelazioidea). Acta Parasitol. 55: 144-160.

Moravec F., Bilal S.J., Abdullah S.M.A. 2012a: Two species of Rhabdochona (Nematoda: Rhabdochonidae) from the cyprinid fish Luciobarbus kersin (Heckel) in northern Iraq, including R. (Globochona) kurdistanensis sp. n. Folia Parasitol. 59: 139-147.

Moravec F., Ermolenko A.V., Besprozvannykh V.V., Scholz T. 2012d: New data on the morphology of some Far-Eastern species of Rhabdochona (Nematoda: Rhabdochonidae), as revealed by SEM observations. Folia Parasitol. 59: 195-208.

Moravec F., Fiala I., Dyková I. 2004: Philometra thaiensis sp. nov. (Nematoda, Philometridae) from Tetraodon palembangensis and T. fluviatilis (Pisces) from fresh waters in Thailand, with a key to Philometra spp. parasitic in the host's abdominal cavity. Acta Parasitol. 49: 319-324.

Moravec F., Fiala I., Dyková I. 2011: New data on the morphology of Dichelyne hartwichi (Nematoda: Cucullanidae), a parasite of freshwater tetraodontid fishes (Tetraodon spp.) in Thailand. Acta Parasitol. 56: 433-437. 
Moravec F., Salgado-Maldonado G., González-Solís D., Caspeta-Mandujano J.M. 2012c: Host-parasite relationships of Rhabdochona kidderi Pearse, 1936 (Nematoda Rhabdochonidae) in fishes of the Lacantún River in the Lacandon rain forest of Chiapas State, southern Mexico, with a key to Mexican species of Rhabdochona Railliet, 1916. Syst. Parasitol. 82: 1-12.

Moravec F., Scholz T. 1991: Observations on some nematodes parasitic in freshwater fishes in Laos. Folia Parasitol. 38: 163$178+$ Plts. I-VIII.

Moravec F., Scholz T., Ash A., Kar P.K. 2010: New data on the morphology and taxonomy of three species of Rhabdochona (Nematoda: Rhabdochonidae) parasitizing fishes in India. Folia Parasitol. 57: 295-306.

Moravec F., Sheeba S., Kumar A.B. 2012b: Rhabdochona (Rhabdochona) keralaensis sp. nov. (Rhabdochonidae) and some other nematodes in the Indian mottled eel Anguilla bengalensis bengalensis from India. Acta Parasitol. 57: 74-82.

Moravec F., Taraschewsi H., Thairungroj Anantaphruti M., Maipanich W., Laoprasert T. 2006: Procamallanus (Spirocamallanus) anguillae sp. n. (Camallanidae) and some other nematodes from the Indonesian shortfin eel Anguilla bicolor in Thailand. Parasitol. Res. 100: 69-75.

Moravec F., Taraschewski H., Thairungroj Anantaphruti M., Maipanich W., LaOprasert T. 2007: Heliconema longissimum (Ortlepp, 1923) (Nematoda: Physalopteridae) from Pisodonophis boro (Teleostei: Ophichthidae) in Thailand, with remarks on the taxonomy of the Proleptinae Schulz, 1927. Syst. Parasitol. 66: 73-80.

Moravec F., Wolter J., Körting W. 1999: Some nematodes and acanthocephalans from exotic ornamental freshwater fishes imported into Germany. Folia Parasitol. 46: 296-310.

Moravec F., Yooyen T. 2011a: Two new species of Rhabdochona (Nematoda: Rhabdochonidae) from freshwater fishes in Thailand. Folia Parasitol. 58: 224-232.
Moravec F., Yooyen T. 2011b: Observations on two nematode species parasitizing freshwater fishes in Thailand, including Spinitectus thaiensis sp. nov. (Cystidicolidae) from Pseudomystus siamensis (Bagridae). Acta Parasitol. 56: 58-66.

Pearse A.S. 1933: Parasites of Siamese fishes and crustaceans. J. Siam. Soc. Nat. Hist. 9 (Suppl.): 179-181.

Purivirojkul W. 2009: Fish parasite diversity in the Mekong River in the north of Thailand. Khon Kaen Univ. Sci. J. 37 (Suppl.): $62-70$.

Puylaert F.A. 1973: Rhabdochonidae parasites de poissons africains d'eau douce et discussion sur la position systématique de ce groupe (Vermes - Nematode). Rev. Zool. Bot. Afr. 87: 647-665.

RatanasRitong S., Kliks M. 1972: A survey of the helminth parasites of freshwater fish in Chiang Mai Province. Bull. Chiang Mai Med. Technol. 5: 185-200.

Sirikanchana P. 1982: Check Lists of Parasites of Fishes in Thailand. Kasetsart University Museum of Fisheries, Bangkok, Thailand, $11 \mathrm{pp}$.

Soota T.D., Dey Sarkar S.R. 1981: On some nematodes from Solan District, Himachal Pradesh, India. Rec. Zool. Surv. India 79: 169-177.

WANG G., Yu Y., Wu H. 1994: Studies on two new species of Rhabdochona (parasitic nematodes) from Wuling Mountain Region. Acta Hydrobiol. Sin. 18: 280-286. (In Chinese with English summary.)

Wang P., Guo Q. 1983: Studies on some species of helminths from freshwater fishes in Yunnan, China. Oceanol. Limnol. Sin. 14: 92-102. (In Chinese with English summary.)

Wongsamad C., Rojtinnakorn J., Wongsawad P., Rojanapaibul A., Marayong T., Suwattanacoupt S., Sirikanchana P., Sey O., Jadhav B.V. 2004: Helminths of vertebrates in Mae Sa Stream, Chiang Mai, Thailand. Southeast Asian J. Trop. Med. Publ. Hlth. 35 (Suppl. 1): 140-146.

Accepted 2 August 2012 